\title{
French Representations of Citizenship and Immigrants: \\ The Political Dimension of The Civic Link
}

This is the preprint of an article whose final and definitive form has been published in

Immigrants and Minorities, Volume 22, Numbers 2 \& 3, July/November 2003, p. 262-279.

\author{
Sophie Duchesne
}

\begin{abstract}
Summary:
Representations of, and attitudes towards, foreigners take place within the complex system of values and meaning that constitutes what we call a national identity. In the French case, different conceptions of citizenship give rise to different attitudes towards immigrants. These conceptions, even if they could be related to antagonistic theories of democracy, blend together within the citizens' representations, giving the opportunity to combine advantages from each model, namely, cohesion and inclusion. But the mix of citizenship representations occurs successfully only when the political dimension of citizenship is accepted. Where this is not the case, the antagonistic potential of both understanding of citizenship and immigrants develops and endangers the coherence of the civic and political national culture.
\end{abstract}

\section{Introduction ${ }^{1}$ :}

It is well known that the way immigrants are received in a country depends on its people's perceptions and conceptions of foreigners. Even if the law governing access to, and settlement in, a specific country is not the mere reflection of public opinion, or even of the voters' will, obviously, this law does incorporate a certain amount of its civic culture. Above all, the integration of migrants in a country does not depend only on the legal framework. It is very much related to everyday interactions between nationals and newcomers, to the way the former accept the latter. Much research has been carried out on the analysis of public attitudes towards foreigners to try and explain the main causes of xenophobia. They demonstrate that attitudes towards strangers are very dependent on social factors but also, that they are very closely related to more general attitudes. ${ }^{2}$ In this paper, based on qualitative data, I would like to show how attitudes are shaped within the complex system of values and meaning that constitutes what we are accustomed to calling a national identity. Indeed, they constitute one single element in the more general question of the evolution and adaptation of national identities and civic cultures in the changing dimension of democracies. ${ }^{3}$ Improving the cultural and political conditions of 
foreigners' reception in a specific country means taking into consideration this whole pattern of meanings and values.

Modern citizenship refers to the nation-state. It has been the framework within which mass democracy has emerged, and has provided status for the new members of political communities in the making, a combination of legally defined rights and duties, but also of norms of behaviour, corresponding to the fact, or the will, that all members of a nation-state should be able to consent, in some degree, to the decisions affecting their lives. But the first steps of mass democracy occurred in a context of restricted mobility of men and goods. The integration of the masses into politics resulted from the invention of nations and the writing of histories linking the citizens to their states: people's self-esteem has been strengthened by their nation's history, their glorious heritage, in exchange for their peaceful participation in the legitimising process of civic duties $^{4}$. Today, the growing mobility of people is one of the main long-term threats affecting this construction, together with the general increase in education levels that give rise to a concomitant rise in people's expectations concerning their impact on governmental inputs. Other factors include the tendency towards political integration, as in the case of the European Union which challenges the borders of the older nations and, of course, the internationalisation of economies. ${ }^{5}$ The challenge facing democracies is then to find a way of ensuring both cohesion and inclusion ${ }^{6}$ : cohesion, that is, ensuring that citizens will feel and act as members of a common state, as they used to do, or as they were supposed to do; and inclusion, that is the capacity of turning newcomers into members, especially newcomers arriving with an enduring attachment to their former political community. Some authors question the reality of national citizenship today, as they note that the rights and duties traditionally attached to citizenship ${ }^{7}$ no longer depend on belonging to the national community, at least for most of these rights and duties. ${ }^{8}$ But most specialists consider that a national citizenship is a necessity as the states remain the key actors of international politics and still constitute the framework for the implementation of democracy. ${ }^{9}$ The question of the proper access to specific rights for temporary or permanent residents in reference to the rights granted to full citizens has been discussed by a number of important migration specialists engaged in the democratic debate. ${ }^{10}$

Beyond the question of the integration of migrants, political theorists or philosophers have passionate arguments over the right principles and the institutional arrangements which would ensure both the integration of newcomers into the citizenry and the involvement of all old and newcomers - in the practise of citizen's duties. Most of these arguments stumble on the question of the human nature. The appropriate institutional arrangement closely depends on the 
postulated profound motivations of man's behaviour, on the supposed sources of human greatness. Is human spirit heavily dependent on the place and conditions where a person was born and grew up? Or is humanity moved by a universal disposition to rationality? This philosophical question lies behind the exciting debate between communitarians (Taylor, MacIntyre, Walzer or Sandel in particular) and liberals (Rawls's work being the departure point of the debate). Should we build institutions which respect the communities considered as the proper framework for human beings to feel and behave in a responsible way? Or should we develop institutions, which deal only with (free) individuals and whose main purpose is to respect equally the preferences of individual citizens'? ${ }^{11}$ The very concept of nation incorporates this dilemma between distinctive identity and universalism: as Louis Dumont puts it very clearly, 'a nation is the holist conception of individuals. ${ }^{12}$ Furthermore Benedict Anderson based his study of the national imagination ${ }^{13}$ on the observation that the distinctive conception of one's nation has become a universal need. ${ }^{14}$

Concerning integration, this dichotomy between a holistic, particularistic and cohesive conception of the link between citizens and a individualist, universalistic and integrative one ${ }^{15}$ has given rise to a categorisation of nationalism or national consciousness: civic versus ethnic. France and Germany have served as the main examples of this opposition, developed through different point of views and data by such different and famous authors as Louis Dumont and Rogers Brubaker. ${ }^{16}$ France was supposed to have a universalistic conception of citizenship, which dates back to the Revolution and results in a traditional domination of citizenship laws by jus soli. Renan put it well in saying that nation, in the French sense, was a daily plebiscite ${ }^{17}$. In comparison, German national feeling was described as ethnic ${ }^{18}$, dating back to a romantic and organic conception of the Vaterland and still inspiring restrictive naturalisation rates because of citizenship laws based on jus sanguinis. Beyond the cases of France and Germany, the civic and ethnic understanding of nationhood were often valued rather unequally, the ethnic one being considered as less satisfactory than the civic one because of its postulated easier tolerance of, or attractiveness to, xenophobia ${ }^{19}$. The categorisation was based essentially on the study of public discourses and of citizenship laws. That is why the general convergence of citizenship laws in Europe $^{20}$ and the widespread success of nationalist movements there have undermined the efficacy of the dichotomy civic/ethnic understanding of nationhood. ${ }^{21}$

So even if nationalists still try to impose a unique conception of national identity, a homogeneous way of imagining a specific nation and belonging to it, many scholars agree that national consciousness is a complex or composite matter. Observing it from an historical point of view, Bryan Jenkins and Spyros A. Sofos write: 
This raises again the issue of the fundamental ambiguity of nationalism: how membership of the nation is to be defined. As European nation-states established themselves in the period 1870-1918, the open 'citizenship' model (geared to social integration and stabilisation) was merged with an opposite set of principles, culturally or ethnically exclusive (and geared to the marginalisation of the 'unassimilable' and 'enemies of the state'). The tension between the two has remained, and according to political circumstances the emphasis has shifted from one to the other. ${ }^{22}$

The careful study of a specific understanding of nationhood has to account for its complexity and its main tensions. The French case has given rise to this kind of study. Yves Déloye, for instance, has described the tremendous conflict between Catholics and Republicans about the meaning of citizenship and national belonging during the Third Republic (1870-1945) ${ }^{23}$. On a more theoretical level, Dominique Schnapper, in order to work out a heuristic conception of the nation, has reviewed the many different conceptions of the French nation and stressed the main arguments on the matter. ${ }^{24}$ But these arguments, and especially the question of the nature, natural or arbitrary, of the link between fellow citizens, are not restricted to an elite, to intellectuals or politicians; they affect the representations of the citizens and structure them very deeply.

Theoreticians make assumptions on what people are and why they behave as they do. But, if they are given the time to think, citizens can give some insights into the way they relate to others and specifically to their fellow citizens. This may not completely account for their behaviour, as all sociological processes are not visible, ${ }^{25}$ but it can still provide some evidence about the functioning of the political community. When people talk about themselves as citizens they do not speak about themselves as they usually are, but rather about what they think they should be. Nevertheless the way they conceive their role and relate to one another outlines the main features of the national community. If analysed and reconstituted very carefully, the selfrepresentation of a specific citizenry gives an insight into the complex pattern of meanings and values that constitutes a national consciousness and/or a civic culture.

\section{The French case: two models of citizenship. ${ }^{26}$}

Although described through several models, the representations of citizenship in France can be summed up by a single definition: to be a citizen means taking responsibility for one's ties with fellow citizens. But the qualities and roles implied by this definition are directly dependent on how ties among fellow citizens are conceived: according to whether they are considered as natural, concrete, historically-validated ties, or if they appear as arbitrary, artificial ties defined by 
administrative borders. Consequently, two models of citizenship emerge; the first I will call citizenship by inheritance, and the second, citizenship with reservations.

In this definition, politics apparently plays a minor role. Here the description of citizenship is more closely related to what political science refers to as civility. It is the relationship to others that defines what French citizens mean by citizenship, not the relationship to power. Approached with an open methodology ${ }^{27}$ (which excludes pressure or incentives to interviewees to classify and prioritise their values and feelings), the understanding of citizenship does provide an insight into the non-political dimension of national consciousness, that is, the sociological dimension of belonging. ${ }^{28}$ There lies the very difference between nationalism and national consciousness; the first is political by nature, as it is linked to the state and the borders of its power and protection; the second is not, as it is first of all dedicated to the specific group of belonging (one amongst many) that constitutes a nation, and explores the many ways of feeling a part of it, or not. ${ }^{29}$

In more empirical terms, each of the people I met in the course of the study clearly expressed the feeling of having no direct, personal access to power in his/her own right, and therefore no means of consenting, or not, to the decisions that bind him/her. On the other hand, each of the people interviewed also knew that his/her strength with regard to power lay in numbers. If a citizen has power as such (i.e. as a citizen and not because of his/her personal attributes), it is because citizens together are (all) powerful. The power of each citizen depends on the others, on his/her fellow citizens. So it is the relationship he/she has with his/her fellow citizens that defines the limits of his/her power. Thus we can see how ordinary citizenship is described through ties with others, and through the way these ties are fostered and maintained. But the various conceptions about how these ties bind citizens result in differing models of citizenship.

This first one, termed 'citizenship by inheritance', hinges on a 'naturalist', so to speak, conception of ties among fellow citizens. Here a citizen is first and foremost a Frenchman. The model is organized around three words - time, land (the French soil), and family. Land is also the very substance of the inheritance, the heritage, the French land that fellow citizens possess together. It is at the same time the theatre of time passing, land and time being closely linked. This model of citizenship is described by the family metaphor. The family is the link in time and space; it is both the model from which forms of national solidarity are derived and the cause of this solidarity. It is because one belongs to a family, because the members of this family and those of past generations have suffered to make this country what it is, that their heirs, today's citizens, are what they are, and have the means of exercising their citizenship with dignity. The 
national bond, which is the basis of the civic bond, is in fact merely the extension of the family tie from which ideally it takes its form.

In this model, when one says he/she is a French citizen, he/she says who he/she is: he/she is the particular product of a history that has taken place in a particular place, on a specific soil, delimited by set borders. This particularity does not affect him/her, he/she is proud of it, even flaunts it. It gives him/her a substance, a strength that protects him/her. The national element, in this model, draws its force from identification with one's nation. The history of which he/she is a product has an intrinsic weight and significance that partly relieves him/her from having to justify his/her own existence by his/her own achievements. From a certain standpoint, the centuries have done it for him/her. ${ }^{30}$ This is the gist of one interviewee's comment: 'The storm may blow, but I'll be fine, my roots are deeply planted in the ground'. In exchange for a relative powerlessness over the course of things - since, after all, it is on the historical level that things take on meaning: at this level a citizen can do nothing, he/she is insignificant - he/she benefits from the strength and power of his/her nation, that of a whole of which he/she is part. (see Table 1)

\section{Insert Table 1 here}

The second model is very different. It is structured by the opposition between two dimensions of life: what is considered as the legitimate level of existence for citizens, that of individuals and interindividual relationships; and the other one, the collective level. In this model, the citizen only knows (acknowledges) other individuals, meets them and exchanges with them in a totally independent unrestricted manner. The whole problem will be to move from this sphere to the sphere of relationships organized on a societal level, and to find roles that preserve an individual's autonomy and capacity to have exchanges with any other individual. In the realm of 'reservations', the preponderance of relationships between individuals filters through the domination of the 'I/you' pronoun pair, which contrasts with the 'I/we' pair predominant in the first model. The individual exists in the relations he/she establishes with other people, each one taken as an individual. Any encounter with another person is a process of mutual acknowledgment that allows each not only to recognize the other, but also, by reciprocity, to recognize himself. The encounter introduces an identification process that takes place on the singular, unique mode, which presupposes an ability to communicate, to exchange with anyone at all, each confirming the other in his/her reality as a human being, in his claim to universality. The individual is not linked eternally to anything by nature: he/she is apt to change, to be transformed depending on the encounters of the moment. He/she is bound only by his affections. $\mathrm{He} / \mathrm{she}$ rejects any idea of groups or belonging. 'I hate to belong', say the people closest to this model. ${ }^{31}$ 
In this second system of meanings, the frontiers that determine a group - be they official borders setting the administrative limits of a territory or country, or symbolic frontiers of group membership - mark the limits between those who are alike, the members of a group, and those who are different, foreigners. In this sense, all frontiers in this model appear as a negation of the individual, the unique. The people closest to this world vision speak of 'distortion' with regard to the traces left by one's education, which make each individual identifiable as a member of his/her nation, religion, social class or 'race'. Anyone who defines himself/herself otherwise, by the groups he/she belongs to, has lost respect for the human being, respect for the universal which is the only value, the only core of humanity by which an individual knows he/she is a human being.

In this world vision, there is no people, no territory - since there are no legitimate borders to mark out or delimit space - or history: human existence is timeless. An individual's memory is limited to what he/she has experienced, the rest is mere 'distortion', enrolment. Yet the people encountered in the course of this study and who predominantly fit this model know that the world they live in functions differently. As long as they acknowledge that progress exists, they can indeed imagine that it must, in one way or another, produce an accumulation that is not all negative. Still, there is no place on earth for those who want to live alone. Although everyone benefits from progress, no one can escape from it either. One is indebted only for what one has chosen or at least accepted. Hence the individual, morally, owes nothing to society. However, he/she cannot not acknowledge the efforts of those who work, those whose toil produces what he/she benefits from. He/she cannot not acknowledge that they, too, are people like him/her, that they may also feel the weight of society on their shoulders and rebel at the idea of being its prisoner. That is why he/she cannot, without $\underline{\text { reservations }}^{32}$ enjoy the fruit of their efforts and give nothing in return.

In the first model, citizenship represents the efforts a national must make to preserve and develop the country he/she has inherited. In the second, citizenship represents the effort an individual must make to accept the collective dimension of human existence from which he feels remote from the outset but in which he/she will attempt to find a place. To the figure of the traitor - traitor to one's family, one's ancestors, one's country, to what makes it great - that characterizes the lack of civic sense in the first model, the second model substitutes that of the profiteer, one who takes without giving anything in return. But - and it is very important in this model - because each person is the only one capable of assessing the value he/she gives to what he benefits from and the cost of the effort to take part in society, he/she alone determines, at every moment, the level and forms of his/her participation. No one can or should judge what 
another should give. This model is utterly incapable of representing what is imposed as anything but some sort of constraint.

\section{Representations of immigrants in the two models}

Obviously, these two models of citizenship involve different representations of strangers and immigrants. In the first model, the familial metaphor is all pervasive. Per se, strangers should not be a problem as they form the negative image that enables a people to forge its own identity. Moreover, as a family, a people need to include new members regularly in order to continue. Following the rationale behind this model, the problem with immigrants lies in their number: a few immigrants are a source of wealth, a large number a source of poverty because (as the interviewees close to this first model stated) they no longer try to integrate themselves, to find a place in the family. Actually, the people interviewed who were close to this model were very concerned about foreigners or, more precisely, immigrants, even if many of them had rather bad feelings about this rejection. Their ignorance of the interviewer's opinion on the matter largely explains their hesitation to express negative feelings toward immigrants, at least at the beginning of the interview. Later, as confidence increased and the interviewee became reassured that they would not be judged by the interviewer on their opinion, they gradually came to express some of their resentment against those foreigners who have settled in France but do not seem to like the country or the French people. This is the main grievance. Those who immigrate should be willing to find a place in the French community, and should therefore demonstrate their desire to get closer to French people. And this should be a matter of mutual feelings. Anyway, even for those expressing some kind of xenophobia, the greatest danger for a nation in that model does not stem from foreigners but from the citizens themselves; it is their growing individualism, and the fact that they tend more and more to forget what they owe to their ancestors, which is going to destroy the nation. More than European integration, even more than immigration, the interviewees closest to this meaning of life fear the lack of cohesion of the nation, the lack of involvement of their fellow citizens in the community.

In the second model, 'citizenship with reservations', the relationship to immigrants is obviously very different as foreigners do not exist: there are only human beings. In this model, where one is born is due to chance, the hearth does not belong to anyone. The greatness of human beings is that they are able to understand and exchange feelings and ideas with everyone. To consider others as strangers means giving up humanity, and giving way to any kind of indoctrination inherent in collective belonging. To return to the two requirements of present democracy, if the first model lacks inclusiveness, the second lacks cohesiveness. So, this high 
degree of tolerance to foreigners - or rather, this strong interest in different people - goes with an obvious weakness, i.e. lack of involvement in public matters.

This research was qualitative: the interviewees were chosen for their diversity of social backgrounds but obviously do not constitute a representative sample that could allow for a systematic sociological explanation of their representations. Nevertheless, some convergence of the social characteristics of the interviewees closest to each model enables us to take into consideration their main socio-demographic characteristics. The interviewees whose selfrepresentation as citizens is closer to the first model tend to be either retired or at the beginning of their work life or, in the case of women, at the age where their children are grown up and have left home. Few of them have experienced social advancement or geographical or cultural mobility. If we analyze in more details the way social background influences the self representation of a citizen, it seems that the socio-demographic characteristics of those interviewees closer to this model reveal a common feature: a dominant need or desire for integration, for being recognized as a member of a group, which results in a tendency towards identification with the nation in particular. On the other hand, the interviewees whose world vision is closer to the second model demonstrate a prevailing tendency towards individualization, that is, towards the rejection of any kind of belonging. This is in accordance with their social characteristics, as they were fully integrated and had already achieved important progress in the field of integration in terms of career and social advancement.

The two models of citizenship are related to the two conceptions of the human being, which underlie theoretical arguments between communitarians and liberals. One important difference is that, even if they are logically incompatible, these two models do coexist in most of the systems of representations of ordinary French citizens. With the exception of philosophers, who have to be logically consistent, ordinary people do have and express inconsistent representations of themselves and of society. They do feel at the same time part of the whole and a whole in themselves. Their own description of their citizenship fits in part the communitarian conception and, also, partly the liberal one; it derives from both the ethnic and the civic understanding of nationhood. The weight of each model in his/her self-representation differs from one person to another. Some people have either a very particularistic, or a very universalistic conception of themselves; but most of them are in-between and combine elements from the two models.

\section{Comparative data.}


This study, the results of which have been presented above, was not a comparative one. ${ }^{33}$ But the academic literature on British representations of nation and citizenship is rich. It is easy to find evidence of a similar complexity, of a combination of both holistic and individualistic conceptions of the citizens' link. Bikhu Parehk, in his article 'Defining British Identity', stresses this duality of traditions in the public discourses on the subject. ${ }^{34}$ Mikael Hjerm used the data of the International Social Survey Programme of 1995 in order to compare four countries, including Great Britain, with regard to the relationship between national identities, national pride and xenophobia ${ }^{35}$. Referring to the categorisation between civic and ethnic versions of national identity, he classifies the different factors of importance in making British people (or Australian, German or Swedish), namely: to be born in the country, to have lived for most of one's life there, having the citizenship, speaking the language, respecting the country's political institutions and laws and feeling British (or Australian, or German, or Swedish) ${ }^{36}$. The general results of the study show the rarity of an exclusive ethnic conception (from 1.2 in Sweden to 6.8 in Britain) and the high frequency of mixed representations, especially in Britain: 67.3 per cent of British respondents have combined civic and ethnic bases of nationhood. Using a very different methodology - actually, a more comparable way of investigating national feelings with the French study - Pamela Johnston Conover, Ivor M. Crewe and Donald D. Searing have also shown the very mixed nature of British representations of citizenship. In 1991 they published the main results of comparative research (USA / Britain) conducted through focus groups ${ }^{37}$ and meant to test the veracity of some assertions concerning citizens as expressed in the communitarian / liberal debate. They found that 'in the minds of citizens citizenship is a complex matter, and that the roles constructed by citizens themselves blend together liberal and communitarian elements in ways unanticipated by many political theorists. ${ }^{38}$ They interpret the surprising combination of communitarian and liberal arguments found in the study as the evidence of the possibility of having 'some of the benefits of communautarianism in a basically liberal polity ${ }^{39}$

When they speak about their rights, their duties, about what foreigners mean to them, or more generally, about who they think they are as citizens, people reveal the very substance of their 'civic culture' and de facto, of their national identity. A national identity is not a specific understanding of nationhood, a quite homogeneous imagined community elaborated in public discourses in order to give sense to what has happened and is happening in a specific country. This kind of discourse, that can come close to nationalism if used to legitimize a restrictive understanding of nationhood, may influence the national identity of one's country, but not in the short term. This is because a national identity resembles a culture or an ideology, in the anthropological sense ${ }^{40}$, and therefore changes slowly. In the fullest sense of the term, a national 
identity is a complex pattern of meanings and values related to the group whose borders are defined by the state's capacity to intervene, and which underlies the varied representations and attitudes of the citizens towards each other and towards non-citizens, foreigners, immigrants. A national identity is the very complicated combination of the traces of all the stories of the nation heard and experienced by a people. It means that it connects varied - not to say antagonistic understandings of nationhood, and that it is structured not only by positive feelings towards the nation - the bases of belonging to it - but also the many ways of rejecting it, escaping it or resisting the national definition of the self. In this sense, a national identity is the sociological meeting place of the individual and this specific collective that is the nation, a collective that during last decades may have been the main vehicle for learning abstract solidarity. It can be reached only by identifying its constitutive parts, through the in-depth and careful understanding of individuals' representations and reconstituting some of it thanks to their repetitions and associations. Attitudes towards foreigners are just a piece in the jigsaw puzzle of national identity and civic culture, and they cannot be properly understood and analysed independently. The configuration is necessarily a complex and uneven one, as the varied subgroups in a country will display patterns of representation sometimes far removed from the national link. The main purpose of the analysis is precisely to give an account of the many connections that structure a specific national identity.

We have seen that in the case of France, and probably in the British and American cases as reported by Pamela Conover and her colleagues, the representations of the civic and national link combine meanings and values that refer to antagonistic philosophical or theoretical conceptions of the national community. And yet, to a certain extent, this capacity or tolerance to contradiction is beneficial to democracy, because it may allow combining, in the same civic culture, benefits that derive from competitive understandings of the national community. As stated above, contemporary democracy needs cohesion as well as inclusion. On the theoretical level, what gives rise to one tends to prevent the other. The communitarian conception of the national link fosters cohesion whereas the liberal one promotes inclusion. This characteristic of social agents to need both identification and individualisation, and the resulting capacity of citizens to display contradictory representations of themselves, to conceive themselves at the same time in holist and individualist modes, may be one of the solutions to this contemporary democratic dilemma. It may allow, in the French case, for the combination of the cohesive power of citizenship by inheritance and the inclusive power of citizenship with reservation. So, to a certain extent, the lack of demand of logical consistency offers a functional if not a 
philosophically satisfying ${ }^{41}$, solution to the dilemma of present democracy, ensuring both cohesion and inclusion.

However the last point that I would like to make in this paper is that the complex nature of a national identity does not guarantee the positive effect of this coexistence of logically incompatible models. Again, a national identity does include, with the many understandings of the national community experienced by the people, all the corresponding ways of keeping it at a distance, and more particularly, of experiencing one's individuality. The French case study shows empirically that the quiet, peaceful coexistence of the two models of citizenship, the two ways of feeling related to the national community, depends on an independent factor: a dominant political conception of the nation/country.

\section{Insert Figure 1 here}

In order to explain this, I need to introduce the four sub-models that underpin the two main models of citizenship developed in the analysis of the French interviews (see Figure 1). Actually, each of the models of citizenship has two different versions. The first model combines one sub model (let us call it 'nationals'), which is an extension of the traditional Catholic concept of France, with another one (the 'republicans'), which arises from the republican conception of the nation. In the first case, identification with France refers back to an immemorial history, which began centuries ago: France as it has always been, eternal France, that was once called Gaul, and has since managed to keep its identity unaltered. The other sub-model refers to another concept of France: the country of the Revolution, the nation of the little guy versus the big guy, who beheaded a king and declared the Rights of Man and the Citizen. Although (in the first sub-model) xenophobia is well represented, the people whose interviews contributed the most to the second sub-model expressed loudly and clearly their concern not to succumb to racism. The France to which they claim allegiance is a nation that was built out of struggle, a nation inscribed in the dynamics of history, whose project is open to all those who want to participate $^{42}$.

The second model has also two variants. Citizenship with reservations can be read as a challenge: that a human being can take a foothold in society and contribute to improving it, without being drowned out by it, and without blending into the masses or losing his/her humanity. Can one really participate and have a commitment at the collective level, political or otherwise, without losing one's individuality, and without at one point or another letting oneself be 'distorted'? The image that often comes out in the interviews closest to this model is one of political activists who speak like their party leader and can only reproduce ideas developed at the top. The challenge of citizenship begs the question: 'are politicians citizens?' The negative and 
positive responses to this question correspond to the two sub models. Those who believe that politicians are at least commendable for their efforts, and that it is better to take the risk of becoming an apparatchik than remaining a profiteer, will be referred to as 'democrats'; those who do not believe that one can resist the pull of the masses and feel that the main thing is to save one's humanity will be called 'world spectators'.

It appears very clearly, that empirically the connection between the two models of citizenship occurs only by mixing the two sub models 'republicans' and 'democrats'. The interviewees whose representations are very mixed between particularistic and universalistic ones and are able to switch from one conception to another according to the ideas and feelings recalled in the course of their speech, all belong to the republican or democrat sub-models. There is no way to bring closer together conceptions of self and society except from the two other sub models, 'nationals' and the 'world spectators'. The few people whose interviews mixed citizenship by inheritance plus citizenship with reservations but in their apolitical versions, obviously feel uncomfortable with their representation of themselves and confront their ambivalences, which then appear as insuperable contradictions. The positive effect of combining cohesion and inclusion by mixing values and meanings belonging to opposite understandings of the national and civic link is obtained exclusively for people and between people whose representation of the nation or the country includes the idea of project or of change and, more precisely, for people who have a positive conception of politics ${ }^{43}$.

If we extrapolate the findings from the sample to French civic culture, we can make the following hypothesis. The persistent tendency to disparage politics in France - again, not in the sense of the politicians' activity, but in the anthropological sense of the legitimacy of holding diverging and conflictive views about the main purpose of the national community - in the last decades is slowly destroying the capacity of French national identity to combine two antagonistic understandings of the nation inherited from the past and to benefit from the advantages of both of them, the cohesive power of the republican and Catholic models and the inclusive potential of the democratic and Christian one.

\section{Conclusion:}

If the integration of migrants is a question per se in the perspective of human rights, it is inseparable from the problem of cohesion or involvement in the political community when considered in relation to democracy. Public discourses and citizenship laws are important indicators of the capacity of a specific country to integrate migrants. But consideration of both inclusion and cohesion may also require attention to the civic culture or the national identity of 
the host country, if national identity is conceived as the whole system of meanings and values of the citizens in relation to the national community. This system is a very complex one, which includes understanding of belonging to the nation as well as feelings of distance and individualisation. It combines antagonistic elements, meanings and values, more or less bound up together. The way the system brings together cohesive values with inclusive ones is of paramount importance for current democratic systems.

In the case of France, the combination of meanings inherited from competing understanding of citizenship, but necessary to endow the democratic process with both cohesion and inclusion, requires a positive evaluation of the very notion of politics. One of the many explanations of what happened at the 2002 presidential election is that the lack of political alternatives and projects in the last decade, and the growing conviction that nobody can change the course of events, has ruined the link between two understandings of citizenship - citizenships by inheritance or with reservations - and pushed back the representations that French people have of themselves to the exclusive and anomic versions of these representations - the nationals' and world spectators' versions. The loss of faith in the power of politics to bring about change has revived the dilemma of democracy between cohesion and inclusion.

Paper submitted to Immigrants and Minorities, within a special issue directed par Richard Lawless and Ahmed Al Shahi. Last revision October 2003. 


\begin{tabular}{|l|l|l|}
\hline \multicolumn{3}{|c|}{ Table 1: Summary of the Two Empirical Models of French citizenship } \\
\hline & "Citizenship by inheritance" & "Citizenship with reservations " \\
\hline Subjects & I, we & I, you \\
\hline $\begin{array}{l}\text { Characteristic of the } \\
\text { community }\end{array}$ & Unity and difference & Diversity and anonymity \\
\hline Identity & Belonging & Independence \\
\hline Loosing one's citizenship & To give up, to betray & To choose, to leave \\
\hline Link between citizens & Filiation, love, respect & Empathy, friendship, respect \\
\hline Dynamic & $\begin{array}{l}\text { Memory } \\
\text { To retain and pass on } \\
\text { Past - present - future } \\
\text { Boundaries, points of reference } \\
\text { Soil, territory, borders }\end{array}$ & $\begin{array}{l}\text { Creation } \\
\text { To change and invent } \\
\text { Transformation, break } \\
\text { Restraints, obstacle } \\
\text { Fesert island } \\
\text { Fumily, land }\end{array}$ \\
& $\begin{array}{l}\text { Nature (or God) } \\
\text { Concrete, real }\end{array}$ & $\begin{array}{l}\text { Human being (evolution) } \\
\text { Ideal, imaginary }\end{array}$ \\
\hline Morality & Consciousness and goodwill & Conscience and will \\
\hline & Involvement $=$ integration & Commitment = alienation \\
\hline
\end{tabular}


Figure 1: Sub-Models of French Representations of Citizenship

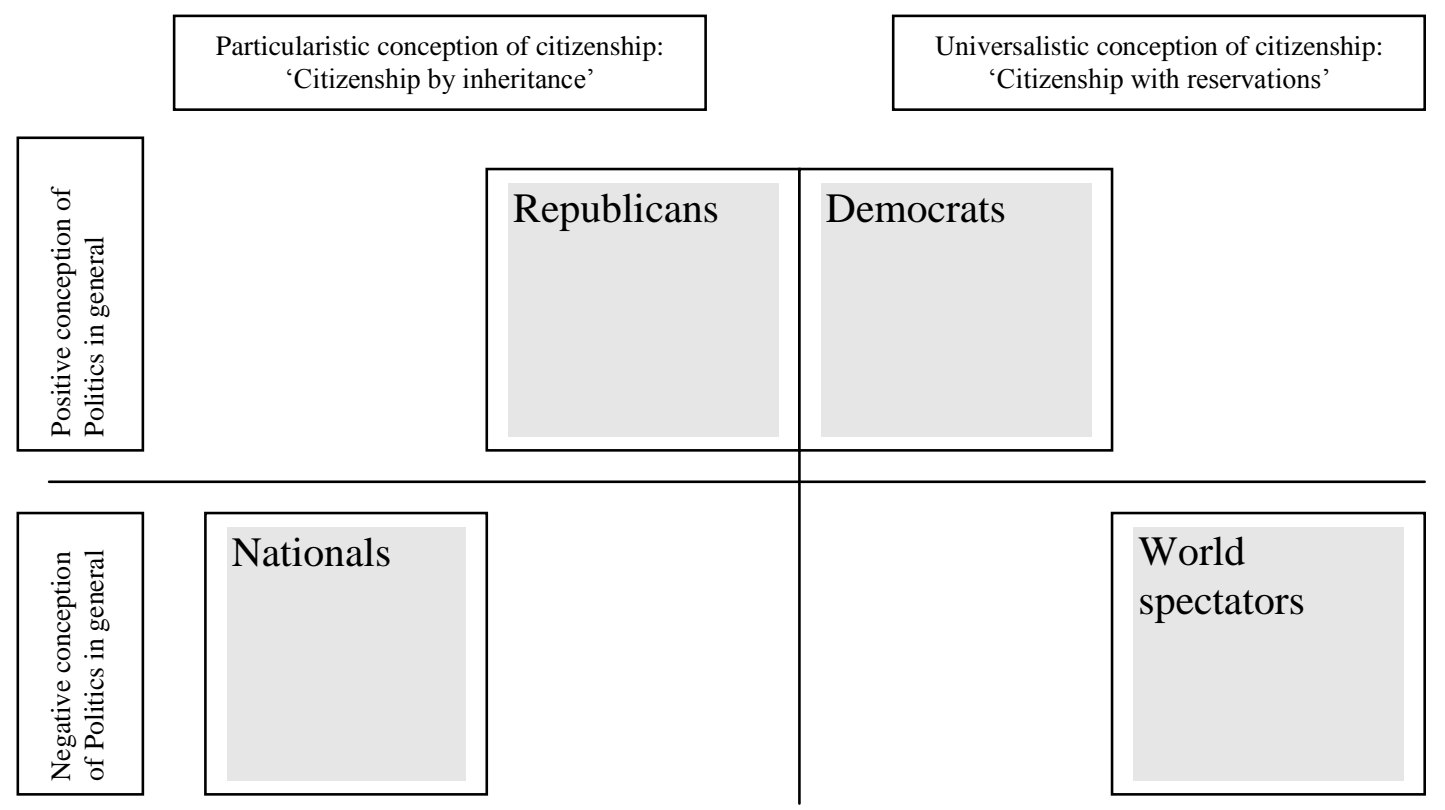

1 I would like to thank Florence Haegel and Patrick Le Galès for their comments on the first version of this text, Richard Lawless for the decisive contribution he made regarding the content as well as the form of this paper and Jean-Claude Sergeant for his meticulous reading.

${ }^{2}$ In the French case at least xenophobia varies heavily with age, educational level and social status, but is also very dependent on political attitudes and partisan orientation. For a recent summary, see Pierre Bréchon ed., Les valeurs des Français (Paris, Armand Colin, 2002) (ch. 6).

${ }^{3}$ It should be noted that this paper is not by a specialist on immigration. On the contrary: when I began to work on citizenship, many academics in France were already involved in the study of the citizen's representations of the so called 'deuxième génération' - that is, of the daughters and sons of immigrants in France. I thought that in order fully to understand the civic expectations of new citizens, we needed to know more about the civic conceptions of their 'elder' counterparts. Consequently I made a qualitative study, with in-depth interviews, of the citizen's representations of non-immigrants in France. See S. Duchesne, Citoyenneté à la Française (Paris, Presses de Sciences Po, 1997).

4 The modern construction of nations has been told and explained brilliantly both by Eric J. Hobsbawm in his Nations and nationalism since 1780: programme, myth, reality (Cambridge, CUP, 1990) and Ernest Gellner in Nations and nationalism (Oxford, Basil Blackwell 1983). Other authors have focussed on the link between nation building and mass democracy, in France particularly. See for instance Pierre Rosanvallon, Le peuple introuvable : histoire de la représentation démocratique en France (Paris, Gallimard, 1998) or Yves Deloye, Sociologie historique du politique (Paris, La Decouverte, 1997).

5 Didier Lapeyronnie : L'individu et les minorités : la France et la Grande-Bretagne face à leurs immigrés (Paris, Presses Universitaires de France, 1993).

${ }^{6}$ Jean Leca, 'La citoyenneté entre la nation et la société civile' in D. Colas, Cl. Emeri et J. Zylberberg eds. Citoyenneté et nationalité : perspectives en France et au Québec (Paris, PUF, 1991).

${ }^{7}$ Following T. H. Marshall, these rights are usually classified as civil, political and social rights (cf. Citizenship and social class : and other essays, T. H. Marshall, Cambridge, CUP, 1950), but some multiculturalists think that the typology could now be completed with a cultural category (see Michel Wieviorka, Une société fragmentée ? Le multiculturalisme en débat, Paris, La Découverte, 1997).

${ }^{8}$ For instance Yasemin N. Soysal, Limits of Citizenship: Migrants and Postnational Membership in Europe (Chicago Ill., University of Chicago Press, 1994).

9 See Rogers Brubaker and its famous Citizenship and nationhood in France and Germany (Cambridge, Mass., Harvard University Press, 1992). But also, for instance, David Miller, On nationality (Oxford, Clarendon Press, 1995).

${ }^{10}$ See for example Stephen Castles, Ethnicity and Globalization : from Migrant Worker to Transnational Citizen (London, Sage, 2000). Catherine Wihtol de Wenden, L'immigration en Europe (Paris, La Documentation Francaise, 1999). Or Etienne Balibar, Race, Nation, Class: Ambiguous Identities (London, Verso, 1991). 
11 Of course, the debate is much more subtle than that. For an introduction, see Daniel Bell; 'Communitarianism', The Stanford Encyclopedia of Philosophy (Winter 2001 Edition), Edward N. Zalta (ed.), URL = http://plato.stanford.edu/archives/win2001/entries/communitarianism/ and for a more extensive presentation of the arguments and the numerous contributions, see Stephen Mulhall and Adam Swift, Liberals and communitarians (Oxford, Blackwell, 1996).

12 L. Dumont, Essays on Individualism: Modern Ideology in Anthropological Perspective (Chicago, London, University of Chicago Press, 1986).

13 This is the way 'Imagined Communities' as been translated in French. Cf. B. Anderson, Imagined Communities; Reflections on the Origin and Spread of Nationalism (London, Verso, 1983), translated as: L'imaginaire national: réflexions sur l'origine et l'essor du nationalisme in 1996.

${ }^{14}$ See in the introduction the three paradoxes presented by Benedict Anderson as starting points of his analysis.

15 This dichotomy also coincides with the sociological distinction between Gesellschat and Gemeinschaft introduced by Ferdinand Tönnies (cf. Community \& society, East Lansing, Michigan State University Press, 1957) which is also at the core of the durkheimian distinction between organic and mechanical solidarity (cf. The rules of sociological method, and selected texts on sociology and its method, London, Macmillan, 1982)

${ }^{16}$ Louis Dumont, German Ideology: from France to Germany and Back (Chicago, London, University of Chicago Press, 1994). R. Brubaker, Citizenship and Nationhood in France and Germany, op.cit.

${ }_{17}^{17}$ Ernest Renan, Qu'est-ce qu'une nation? Conference faite en Sorbonne le 11 mars 1882 (Paris, Presses Pocket, coll. Agora, 1992)

${ }^{18}$ See also S. Castles \& M. J. Miller, The Age of Migration (London, Macmillan, 1993).

${ }^{19}$ Mikael Hjerm, "National Identities, National Pride and Xenophobia: a Comparison of Four Western Countries", Acta Sociologica, vol.41 (1998) p.335-47.

${ }^{20}$ Patrick Weil et Randall Hansen dir., Nationalité et citoyenneté en Europe (Paris, La Découverte, 1999).

${ }^{21}$ Rogers Brubaker, whose first book contributed to the widespread use of the civic/ethnic categorisation, has then refuted it very clearly, but on a different basis: because of the general reprobation given to eastern nationalisms, qualified as ethnic ones. Instead, Brubaker promotes another dichotomy, referring to the historical context of expression of the national link - state-frames versus counter-state nationalism - but independent of its nature: 'Quite apart from the difference, mentioned above, between narrowly ethnic and broadly ethno cultural understandings of nationhood, counter-state definitions of nation may be based on territory, on historic provincial privileges, on distinct political histories prior to incorporation into a larger state and so on. These are all cases of counter-state but non-ethnic definitions of nationhood - of nation defined in opposition to the institutional and territorial framework of an existing state or states but without reference to a distinct ethnic or ethno cultural collectivity." (R. Brubaker, "Myths and misconceptions in the study of nationalism", in John Hall ed., The State of the Nation: Ernest Gellner and the Theory of Nationalism (Cambridge, Cambridge University Press, 1998, p. 301)

22 B. Jenkins and S. A. Sofos, Introduction of Nation and Identity in Contemporary Europe (London and New York, Routledge, 1996, p. 28).

${ }^{23}$ Y. Déloye, Ecole et citoyenneté. L'individualisme républicain de Jules Ferry à Vich : controverses (Paris, Presses de la FNSP, 1994).

${ }^{24}$ D. Schnapper, Community of Citizens: on the Modern Idea of Nationality (New Brunswick, N. J., Transactions, 1998)

25 This cannot be done by a quick interrogation. You cannot expect people to be able to express in a few minutes, spontaneously, what they are, why they behave as they do. Trying to understand how citizens represent themselves, how they perceive the political community which they belong to, the articulation of meanings which lies at the core of their political culture require time, both at the stage of data collection and at the stage of data interpretation. I agree with Pierre Bourdieu that "social agents do not innately possess a science of what they are and what they do." ("Understanding" in P. Bourdieu dir., The Weight of the World. Social Suffering in Contemporary Society, Cambridge, Polity Press, 1999, p. 620). But I believe that the sociologist's capacity to explain forces and processes that people themselves do not realise, is due to the resources - and, first of all, the time - that the researcher has at his disposal, and not to a specific nature of sociological knowledge. For more details, see J.-M. Donegani, S. Duchesne and F. Haegel, «Sur l'interprétation des entretiens de recherche» in J.-M. Donegani, S. Duchesne and F. Haegel (eds.), Aux Frontières des attitudes. Textes en hommage à Guy Michelat (Paris, L'Harmattan, 2002), p. 272-295.

${ }_{26}$ This in-depth understanding of the relationship between citizens, of the nature of civic and/or political links in France was the main purpose of my doctoral dissertation (Citoyenneté à la Française : la tension entre universalisme et particularisme. Analyse d'entretiens non-directifs, 1994). This summary of the models of citizenship is taken up from an article published in the Tocqueville Review ('To be someone, but somewhere: ordinary representations of citizenship in France', vol.20 n¹, 1999, p.99-118), but the labels of the main models have been changed according to Richard Lawless's suggestion.

${ }^{27}$ The interviews were adapted from the non-directive approach established in the 1960s with a dual reference to the first experiments of industrial action research (see F J. Roethlisberger, W. J. Dickson and H. A. Wright, Management and the Worker (an Account of a Research Program Conducted by the Western Electric Company, Hawthorn Works, Chicago), Cambridge, Mass., Harvard University Press, 1947) and to the rogerian method of counseling (see C. R. Rogers, "The Non-Directive Method as a Technique for Social Research", American Journal of Sociology, n 50(4), 
(Jan.1945), p.279-89). For a presentation of the methodology of collecting interviews, see S. Duchesne, Pratique de l'entretien dit 'non-directif', in Les méthodes au concret. Démarches, formes de l'expérience et terrains d'investigation en science politique, Myriam Bachir dir. (Paris, PUF, 2000, coll. Curapp, p. 9-30) and concerning the method of analysis, see J. M. Donegani, S. Duchesne and F. Haegel, 'Sur l'interprétation des entretiens', op. cit.

${ }^{28}$ For an empirical but quantitative demonstration of the dual dimension of national belonging, see S. Duchesne \& A. P. Frognier: 'Sur les dynamiques sociologiques et politiques de l'identification à l'Europe', RFSP, vol. 52(4), Août 2002, p. 355-373. For a more abstract discussion of identities and political identities, S. Duchesne \& V. Scherrer, 'L'identité politique comme force de combinaison et de conflictualisation des appartenances sociales : justification théorique d'une définition empirique', to be published in the collected papers of the international conference Identité(s), Poitiers, janvier 2002 :

http://www.mfo.ac.uk/ site/mfo f/cnrs f/cnr cher f/cnr cher duchesne f/cnr cher duch iden f.htm

${ }^{29}$ Jenkins and Spyros, also in a more engaged style, come to the same conclusions: "Those who would oppose the more negative forms of nationalism that today appear to be in the ascendancy need, however, to adopt an appropriate strategy, based on a proper understanding of what they are dealing with. This involves recognition, first of all, that national sentiments are still deeply entrenched, and that they will not be transcended simply by a refusal to acknowledge them. Affection for one's social and special environment is not inherently negative, indeed it may be seen as a valuable source of cultural diversity in an increasingly homogenized world. Neither is it necessarily 'political' in its raw state, though as we have seen it is 'malleable'.' (Jenkins \& Spyros, " introduction », op. cit. p. 29)

30 Some interviewees display a certain commiseration towards Americans, citizens 'who have no history', or have such a brief one that it is unable to justify, as French history does, the existence of the people descended from it.

31 In the interviews closest to this model, two images of the collective body are predominant: the aimless crowd wandering through supermarkets, in the subway, people who disturb each other, step on each other's toes without even looking at one another; or the conscripted crowd, let loose, driven only by the will to kill or destroy, the army marching forward in which each soldier only knows how to obey, or the people in revolt.

${ }^{32}$ The model's name comes from this, the word used in the French interviews being "scrupules".

33 To a certain extent, the case study may have made it easier to consider the diversity of French representations. In a comparison, we tend to simplify each case in order to stress the differences and similarities between them, as very complex cases may be too difficult to compare.

${ }^{34}$ Bhiku Parekh, 'Defining British National Identity', The Political Quarterly, vol.71(1), Jan. 2000, p.4-14.

${ }^{35}$ Mikael Hjerm, "National Identities, National Pride and Xenophobia", op. cit.

${ }^{36}$ His way of categorizing the items could be debated, as he acknowledges in the article: he considers that being born in one's country and having lived there for most of one's life as the indicators of an ethnic national identity; respect for political institutions and having citizenship as well as feeling British (or Swedish etc.) and speaking the language as indicators of the civic one. But his classification is based on a cluster analysis that gives evidence for the link between the two first items.

37 Pamela J. Conover, Ivor M. Crewe and Donald D. Searing, 'The Nature of Citizenship in the United States and Great Britain: Empirical Comments on Theoretical Themes', The journal of Politics, vol. 53(3), August 1991, p. 800832. Eight groups have been interviewed, four in each country, two in a rural area and two in a urban context in each case, gathering between 7 and 11 persons each.

38 P. Conover, I. Crewe and D. Searing, 'The Nature of Citizenship...', op. cit., p. 800.

${ }^{39}$ P. Conover, I. Crewe and D. Searing, 'The Nature of Citizenship...', op. cit., p. 826.

40 Believing, with Max Weber, than man is an animal suspended in webs of significance he himself has spun, I take culture to be those webs, and the analysis of it to be therefore not an experimental science in search of law but an interpretive one in search of meaning.' Clifford Geertz, The Interpretation of Cultures (London, Basic books, 1975), p. 5.

${ }^{41}$ I spent a long time during work on my doctoral dissertation to find a way to resolve what I called the 'tension of French citizenship'. My supervisor, Prof. Jean Leca, whose work is mainly theoretical, was obviously dissatisfied with the lack of consistency of my interviewees and the corresponding lack of consistency of the models I was constructing. But I am more and more convinced that political sociology does not pay enough attention to the inconsistency of people.

42 Even if, as said before, they insist on the time needed by a person to merge into the nation's destiny: a lifetime at least, if not more than a generation. They believe that a nation evolves like a family, in which successive marriages provide a steady supply of new blood. But it takes determination on both sides for assimilation into the family to be successful.

43 A positive conception of politics, but in the broader sense: people who believe that the way things are going is not given, that human beings can fight for a better world. For a review of the many researchers involved in an extension of the notion of politics, see for instance the introduction of Nina Eliasoph's Avoiding Politics: How Americans produce Apathy in Everyday Life (Cambridge, CUP, 1996) This positive conception of politics does not presuppose a positive representation of politicians: in these interviews, as in almost all interviews recorded in France in the last decade, politicians have an awful reputation. But this is not specific to France. 